\section{BRAZIULIAN JOURNAL \\ OF MEDICAL AND BIOLOGICAL RESF.ARCH}

www.bjournal.com.br
ISSN 0100-879X

Volume 43 (04) 325-408

April 2010

BIOMEDICAL SCIENCES

AND

CLINICAL INVESTIGATION

Braz J Med Biol Res, March 2010, Volume 43(4) 345-349

Antifungal activity of the naphthoquinone beta-lapachone against disseminated infection with Cryptococcus neoformans var. neoformans in dexamethasone-immunosuppressed Swiss mice

C.S. Medeiros, N.T. Pontes-Filho, C.A. Camara, J.V. Lima-Filho, P.C. Oliveira, S.A. Lemos, A.F.G. Leal, J.O.C. Brandão and R.P. Neves

The Brazilian Journal of Medical and Biological Research is partially financed by
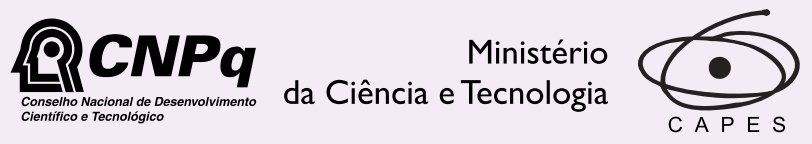

Ministério
da Educação

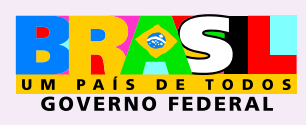

Institutional Sponsors 


\title{
Antifungal activity of the naphthoquinone beta- lapachone against disseminated infection with Cryptococcus neoformans var. neoformans in dexamethasone-immunosuppressed Swiss mice
}

\author{
C.S. Medeiros ${ }^{1}$, N.T. Pontes-Filho ${ }^{2}$, C.A. Camara ${ }^{4}$, J.V. Lima-Filho ${ }^{5}$, \\ P.C. Oliveira ${ }^{1}$, S.A. Lemos ${ }^{1}$, A.F.G. Leal ${ }^{1}$, J.O.C. Brandão ${ }^{3}$ and R.P. Neves ${ }^{1}$ \\ ${ }^{1}$ Departamento de Micologia, ${ }^{2}$ Departamento de Patologia, ${ }^{3}$ Departamento de Energia Nuclear, \\ Universidade Federal de Pernambuco, Recife, PE, Brasil \\ ${ }^{4}$ Departamento de Química, ${ }^{5}$ Departamento de Biologia, Universidade Federal Rural de Pernambuco, \\ Recife, PE, Brasil
}

\begin{abstract}
The in vivo antifungal activity of the naphthoquinone beta-lapachone against disseminated infection by Cryptococcus neoformans was investigated. Swiss mice were immunosuppressed daily with dexamethasone $(0.5 \mathrm{mg}$ per mouse) intraperitoneally for 3 days, the procedure was repeated 4 days later, and the animals were then challenged intravenously with $C$. neoformans $\left(10^{6}\right.$ $\mathrm{CFU} / \mathrm{mL}) 1$ week later. Seven days after infection, the mice were divided into groups and treated daily with beta-lapachone (10 $\mathrm{mg} / \mathrm{kg}, i \mathrm{v})$ for $7(\mathrm{~N}=6)$ and 14 days $(\mathrm{N}=10)$. Amphotericin $\mathrm{B}(0.5 \mathrm{mg} / \mathrm{kg})$ was used as comparator drug and an additional group received PBS. Treatment with beta-lapachone cleared the yeast from the spleen and liver, and the fungal burden decreased approximately $10^{4}$ times in the lungs and brain 14 days after infection when compared to the PBS group $(P<0.05)$. This result was similar to that of the amphotericin B-treated group. Protection was suggestively due to in vivo antifungal activity of this drug and apparently not influenced by activation of the immune response, due to similar leukocyte cell counts among all groups. This study highlights the prospective use of beta-lapachone for treatment of disseminated cryptococcosis.
\end{abstract}

Key words: Beta-lapachone; Cryptococcus neoformans; Cryptococcosis; Immunosuppression; Experimental infection; Amphotericin B

\section{Introduction}

Cryptococcosis is an opportunistic systemic mycosis that especially affects immunocompromised patients (1). Patients infected with HIV, cancer patients, diabetics, patients submitted to transplants or invasive procedures, or people taking corticosteroids are especially susceptible to the disease. Primary cryptococcal infection starts in the lungs and commonly disseminates to several organs (2). However, the yeast shows tropism for the central nervous system, where it survives and proliferates, causing meningitis and meningoencephalitis, both of which can be fatal if not treated properly (3). Two major strains of Cryptococcus neoformans have been described: C. neoformans var. neoformans, which is most commonly detected in immunodeficient hosts, and $C$. neoformans var. gattii, which is more frequently isolated from immunocompetent hosts (4). Cryptococcosis is treated with amphotericin B/azoles as the main therapeutic choice (5). Nevertheless, the high lethality rate among immunocompromised patients indicates that new therapeutic options are necessary.

Natural products or derived substances with antifungal properties have been used to manage cryptococcosis. Some examples are plant essential oils, which have been extensively tested due to their antimicrobial properties (6). Beta-lapachone is synthesized from lapachol derived from Tabebuia avellanedae (popular name: Ipê roxo), a plant of the Bignoneaceae family commonly found in many regions of Brazil. This naphthoquinone was reported to have anticancer, anti-Trypanosoma and antibacterial properties (7-9).

Correspondence: J.V. Lima-Filho, Laboratório de Microbiologia e Imunologia, Departamento de Biologia, Rua Dom Manuel de Medeiros, s/n, Campus Dois Irmãos, 52171-900 Recife, PE, Brasil. E-mail: jvitor@db.ufrpe.br and rejadel@yahoo.com.br 
Previous studies showing antifungal activity of lapachol and beta-lapachone against $C$. neoformans are to some extent contradictory because of the different experimental protocols used (10). Nevertheless, these data indicate that new studies are necessary before proposing antifungal tests on humans.

In the present study, the role of the naphthoquinone beta-lapachone in controlling disseminated cryptococcosis was evaluated in a murine model of dexamethasoneimmunosupressed Swiss mice.

\section{Material and Methods}

\section{Synthesis of beta-lapachone}

Beta-lapachone was synthesized from naturally occurring lapachol derived from T. avellanedae (Bignoneaceae) using sulfuric acid according to a method from Cavalcante et al. (11).

\section{C. neoformans URM5811}

We have tested 16 yeast isolates of C. neoformans stored in the Culture Collection of the URM Micoteca of Pernambuco Federal University for in vitro sensitivity to beta-lapachone by standard methods (12) (data not shown). The minimum inhibitory concentration and minimum fungicidal concentration for beta-lapachone was 4 and $64 \mathrm{mg} / \mathrm{L}$, respectively. C. neoformans var. neoformans URM5811 was obtained from an AIDS patient and used due to its high virulence and in vitro sensitivity to beta-lapachone.

\section{Animals and immunosuppression protocol}

Adult male Swiss mice, $30 \mathrm{~g}$, were obtained from the Keizo-Azami Immunopathology Laboratory (LIKA/UFPE). The animals were handled according to established experimental procedures following approval by the Animal Ethics Committee of the Pernambuco Federal University (protocol \#013968/2007-1). The immunosuppression protocol was adapted from Capilla et al. (13). The mice received $0.5 \mathrm{mg} /$ mouse dexamethasone (Teuto ${ }^{\circledR}$, Brazil) intraperitoneally for 3 days and then 4 days thereafter in all experiments. Total leukocyte enumeration in the blood of the immunosupressed (IS) mice in comparison to the immunocompetent (IC) animals was used to confirm immunosuppression.

\section{C. neoformans infection model}

Seven days after the beginning of immunossupression, the animals $(\mathrm{N}=6)$ were challenged with $0.2 \mathrm{~mL} C$. neoformans URM5811 ( $10^{6}$ cells $\left./ \mathrm{mL}\right)$ by the tail vein. IC mice ( $\mathrm{N}$ $=6$ ) were used as control and inoculated under the same experimental conditions. The animals were observed daily for clinical signs and for mortality for 14 days.

\section{Cytotoxicity assay on dexamethasone- immunosuppressed mice}

The beta-lapachone doses were chosen based on 12.25 and $25 \%$ of the lethal dose of $80 \mathrm{mg} / \mathrm{kg}$ determined for IC rats (14). The drug was dissolved in $10 \%$ DMSO plus $3 \%$
Tween 80 (v/v in PBS) to produce stock solutions of $100 \mathrm{~g} / \mathrm{L}$. Then, $0.2 \mathrm{~mL}$ of a suspension containing 10 or $20 \mathrm{mg} / \mathrm{kg}$ was administered daily by the tail vein to IS Swiss mice ( $\mathrm{N}=$ $6)$ for 1 week. The control animals $(N=6)$ received only the solvent (10\% DMSO plus 3\% Tween 80 ; v/v in PBS) devoid of beta-lapachone. The animals were observed each day and their liver and kidneys were submitted to histological examination at the end of the experiment.

\section{Treatment of disseminated cryptococcosis with beta-lapachone}

Seven days after infection, $0.2 \mathrm{~mL}$ beta-lapachone (10 $\mathrm{mg} / \mathrm{kg}$ ) was administered daily by the tail vein to IS mice according to two independent schedules: 1) 7 days of treatment $(\mathrm{N}=6)$, or 2) 14 days of treatment $(\mathrm{N}=10)$. Amphotericin B $(0.5 \mathrm{mg} / \mathrm{kg})$ was used for comparison and the untreated animals received only PBS. The animals were observed for clinical signs and for mortality every day until the end of the experiments.

\section{C. neoformans enumeration and histological examination}

An aliquot of blood was collected by cardiac puncture after euthanasia with halothane. The spleen, liver, lungs, and brain were weighed and macerated in PBS (1:10 or $1: 100, w / v)$. All samples were submitted to serial dilutions and $0.1-\mathrm{mL}$ aliquots were added to plates containing SDA plus chloramphenicol $(50 \mathrm{mg} / \mathrm{mL})$ and incubated at $37^{\circ} \mathrm{C}$ for 24-72 h. Data are reported as colony forming units (CFU)/g organ or per $\mathrm{mL}$ blood. Tissues were fixed in $10 \%$ formaldehyde and processed for paraffin embedding. Sections ( $5 \mu \mathrm{m})$ were stained with hematoxylin-eosin and slides were coded and examined by a single pathologist, who was unaware of the experimental conditions of each group.

\section{Statistical analysis}

Data regarding white cell counts and CFU counts were analyzed statistically by the Student $t$-test or ANOVA, with the level of significance set at $\mathrm{P}<0.05$.

\section{Results}

\section{Immunosuppression protocol and C. neoformans infection model}

The immunosuppression protocol applied to the Swiss mice (IS group) resulted in total leukocyte cell counts of approximately 45 and $61 \%$ lower than for the IC group, after 7 and 14 days of infection, respectively $(P<0.05)$. In addition, C. neoformans URM5811 produced a disseminated infection in IS mice that ranged from $10^{4}$ to $10^{6} \mathrm{CFU} / \mathrm{g}$ spleen, liver, lung, and brain 14 days post-infection, whereas IC mice were resistant to cryptococcosis $(P<0.05)$.

\section{In vivo cytotoxicity of beta-lapachone}

Beta-lapachone at $10 \mathrm{mg} / \mathrm{kg}$ was not highly toxic to IS 
mice after daily inocula for 1 week since all animals were healthy and survived during the experiment. Conversely, a dosage of $20 \mathrm{mg} / \mathrm{kg}$ provoked motor imbalance and abdominal contractions after inoculation and lesions in the tail that became necrotic during the experiments, leading to death of some of the animals (33\%). Histological examination of the liver and kidneys showed no morphological alterations at $10 \mathrm{mg} / \mathrm{kg}$ but hydrotropic degeneration of the liver was observed at a dosage of $20 \mathrm{mg} / \mathrm{kg}$.

\section{Treatment of disseminated cryptococcosis with beta-lapachone}

Beta-lapachone treatment $(10 \mathrm{mg} / \mathrm{kg})$ significantly reduced the $C$. neoformans population in the spleen, liver and lungs 7 days after infection (Figure 1A). In addition, the yeast was cleared from the spleen and liver, and fungal burden was reduced approximately $10^{4}$ times in the lungs and brain 14 days post-infection when compared to the PBS group. These results were similar to those obtained with 0.5 $\mathrm{mg} / \mathrm{kg}$ amphotericin $\mathrm{B}$ treatment $(\mathrm{P}<0.05$; Figure 1B). Histological examination showed liquefactive necrosis and cell infiltration in the brain of the beta-lapachone and amphotericin$B$ groups, but less intense than observed in the brain slides of the PBS group (Figure 1C). On the other hand, 4 of 10 mice from the betalapachone group died during the experiments against 1 of 10 in the other groups.

\section{Leukocyte cell counts in beta- lapachone-treated mice}

As expected, the total and differentiated cell counts showed a decrease after 14 days of infection (except for monocyte counts, which remained the same as during the first week) because of dexamethasone administration (Table 1). There were no differences
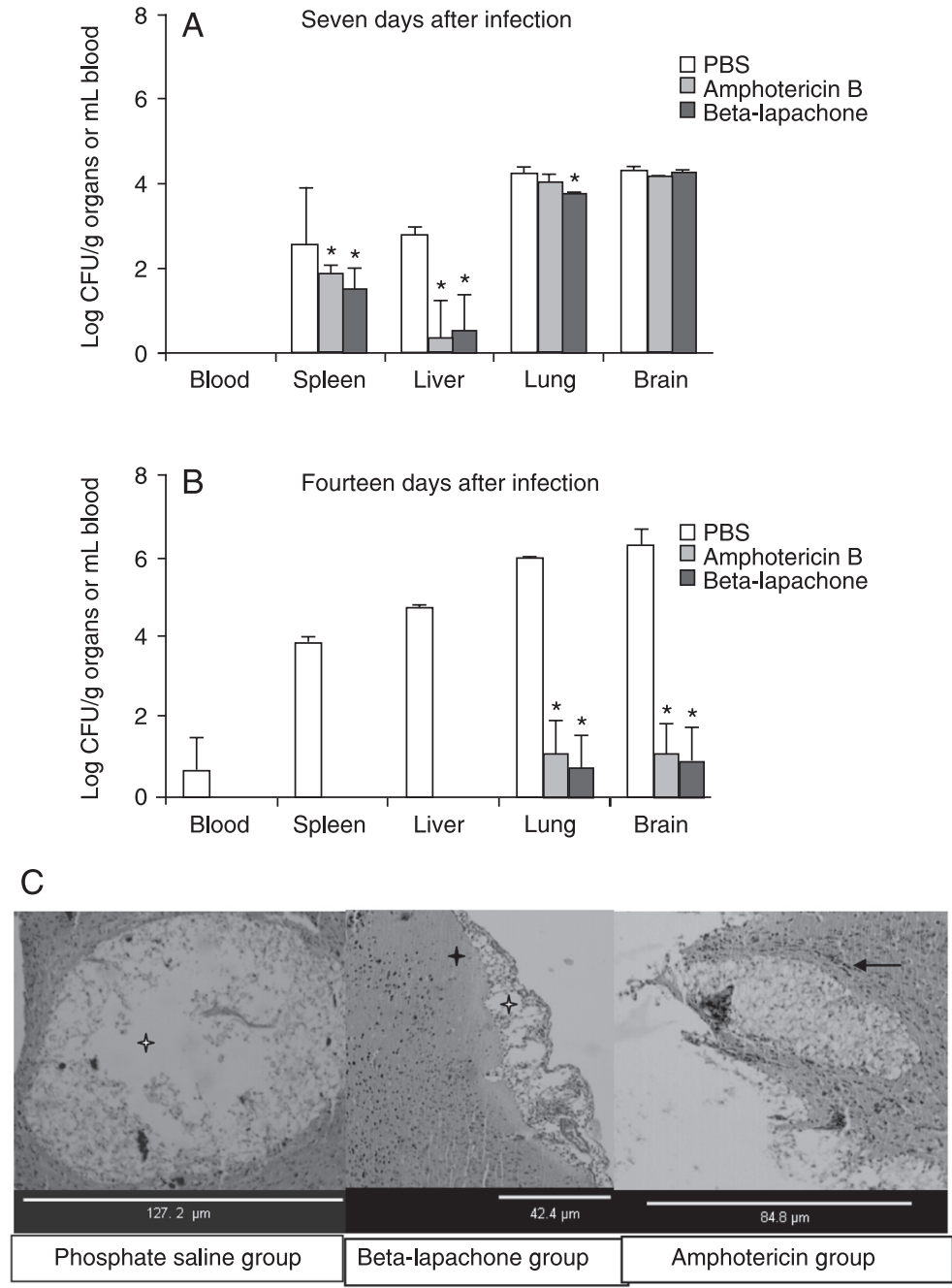

Figure 1. Protective effect of beta-lapachone administration in immunosuppressed Swiss mice challenged with Cryptococcus neoformans URM5811. Seven days after infection, mice were treated daily with PBS, $10 \mathrm{mg} / \mathrm{kg}$ beta-lapachone or $0.5 \mathrm{mg} / \mathrm{kg}$ amphotericin $B$ for 7 (A) or 14 days $(B)$. ${ }^{*} P<0.05$ compared to the PBS group ( $t$-test and ANOVA). The histological damage in the brain 14 days thereafter is shown in Panel C. Liquefactive and coagulative necrosis are indicated by white and black stars, respectively. The arrow indicates inflammatory infiltrates near the lesion.

Table 1. Leukocyte cell counts in dexamethasone-immunosuppressed mice infected with Cryptococcus neoformans strain URM5811 and treated with beta-lapachone.

\begin{tabular}{|c|c|c|c|c|c|c|c|c|}
\hline \multirow[t]{2}{*}{ Animal groups } & \multicolumn{2}{|c|}{ Total leukocyte counts/mL blood } & \multicolumn{2}{|c|}{ Segmented } & \multicolumn{2}{|c|}{ Monocytes } & \multicolumn{2}{|c|}{ Lymphocytes } \\
\hline & 7 days* & 14 days & 7 days* & 14 days & 7 days* & 14 days & 7 days* & 14 days \\
\hline PBS & $2666 \pm 152.75$ & $2166 \pm 173.20$ & $230 \pm 61.33$ & $118 \pm 32.5$ & $165 \pm 4.2$ & $172 \pm 41.05$ & $2309 \pm 95.44$ & $1913 \pm 131.16$ \\
\hline Amphotericin B & $2680 \pm 208.16$ & $2255 \pm 224.22$ & $237 \pm 58.55$ & $148 \pm 36.16$ & $151 \pm 35.26$ & $178 \pm 29.86$ & $2312 \pm 118.76$ & $1973 \pm 239.15$ \\
\hline Beta-lapachone & $2700 \pm 200.0$ & $2133 \pm 163.29$ & $218 \pm 59.57$ & $106 \pm 12.67$ & $162 \pm 48.81$ & $152 \pm 15.13$ & $2320 \pm 132.89$ & $1875 \pm 163.83$ \\
\hline
\end{tabular}

${ }^{*} \mathrm{P}<0.05,7$ days compared to 14 days of treatment per cell group (ANOVA). 
in the cell counts of the different groups.

\section{Discussion}

In the present study, a reliable infection model for experimental cryptococcosis was developed to investigate the ability of the naphthoquinone beta-lapachone to control the disease. However, the lack of pharmacokynetic studies of this drug makes it impossible to anticipate its antifungal properties or toxicity in vivo. Previously, Pereira et al. (8) reported that beta-lapachone was toxic to eukariotic BSC-40 African green monkey kidney cell cultures at concentrations higher than $2 \mathrm{mg} / \mathrm{L}$. Furthermore, one study reported in vivo toxic effects of beta-lapachone in immunocompetent rats (14). Our data show that beta-lapachone at $10 \mathrm{mg} /$ $\mathrm{kg}$ was not notably toxic after 1 week of daily exposure, supporting its use in a $C$. neoformans infection model. In addition, treatment with beta-lapachone reduced the $C$. neoformans population 10,000 times in the lungs and brain and cleared the yeast from the spleen and liver, suggesting that long-term treatment could enhance sterilization in all organs. This protective effect was confirmed by histological examination, which showed that organ damage was less intense than in the PBS group. Conversely, we attributed the animals' death in the beta-lapachone group to some progressively toxic side effect of this drug, since these animals were not especially susceptible to disease, having leukocyte cell counts similar to those of the PBS and amphotericin B groups.

Howland (15) reported that the mechanisms of action of naphthoquinone seem to involve uncoupling oxidative phosphorylation and/or inhibition of cell electron transport. In addition, beta-lapachone increases superoxide anions and hydrogen peroxides, inducing cytotoxicity to Trypanosoma cruzi (7). On the other hand, natural control of $C$. neoformans infection is due to the immune system and

\section{References}

1. Perfect JR, Casadevall A. Cryptococcosis. Infect Dis Clin North Am 2002; 16: 837-874.

2. Barbosa FM, Fonseca FL, Holandino C, Alviano CS, Nimrichter L, Rodrigues ML. Glucuronoxylomannan-mediated interaction of Cryptococcus neoformans with human alveolar cells results in fungal internalization and host cell damage. Microbes Infect 2006; 8: 493-502.

3. Chen SH, Stins MF, Huang SH, Chen YH, Kwon-Chung $\mathrm{KJ}$, Chang $\mathrm{Y}$, et al. Cryptococcus neoformans induces alterations in the cytoskeleton of human brain microvascular endothelial cells. J Med Microbiol 2003; 52: 961-970.

4. Chakrabarti A. Epidemiology of central nervous system mycoses. Neurol India 2007; 55: 191-197.

5. van der Horst CM, Saag MS, Cloud GA, Hamill RJ, Graybill JR, Sobel JD, et al. Treatment of cryptococcal meningitis associated with the acquired immunodeficiency syndrome. National Institute of Allergy and Infectious Diseases Myco- depends on T cell activation in resistant mouse strains (16). Although the mechanism of action of beta-lapachone against cryptococcosis remains unclear, it appears not to be related to activation of the immune system, which could enhance organ clearance. This idea was corroborated by the immune status of Swiss mice during the present experiments, since dexamethasone is known to abrogate $B$ and $T$ cell activation, thereby substantially decreasing humoral and cellular immunity (17). Also, the influence of beta-lapachone on the inhibition of nitric oxide and inducible nitric oxide synthase expression and attenuation of proinflammatory cytokines such as interleukin-1 beta, interleukin- 6 and tumor necrosis factor-alpha have been recently reported (18).

Experimental treatments against disseminated cryptococcosis have been proposed by many investigators. For example, $10 \mathrm{mg} / \mathrm{kg}$ of the triazole SCH56592 significantly decreased the fungal burden of the lungs of laboratory animals, and administration of $4 \mathrm{mg} / \mathrm{kg}$ SPK-843, a new polyene, increased survival and reduced $C$. neoformans colonization in organs $(19,20)$. The present study shows a prospective application of the naphtoquinone beta-lapachone for the management of disseminated cryptococcosis. Although this drug possibly produced localized toxic effects, different dosages and new treatment schedules could be employed. In addition, we believe that beta-lapachone has a protective effect directly against $C$. neoformans cells. These mechanisms of action are under investigation by our research group.

\section{Acknowledgments}

We thank MSc. Maria Helena Madruga Lima Ribeiro (Lika/UFPE) for providing the animals used in this study. The authors thank CNPq for research funding. J.V. LimaFilho was the recipient of a scholarship from the Programa de Educação Tutorial (PET-MEC/SESu). ses Study Group and AIDS Clinical Trials Group. N Engl J Med 1997; 337: 15-21.

6. Mondello F, De Bernardis F, Girolamo A, Salvatore G, Cassone A. In vitro and in vivo activity of tea tree oil against azole-susceptible and -resistant human pathogenic yeasts. J Antimicrob Chemother 2003; 51: 1223-1229.

7. Salas C, Tapia RA, Ciudad K, Armstrong V, Orellana M, Kemmerling U, et al. Trypanosoma cruzi: activities of lapachol and alpha- and beta-lapachone derivatives against epimastigote and trypomastigote forms. Bioorg Med Chem 2008; 16: 668-674.

8. Pereira EM, Machado TB, Leal IC, Jesus DM, Damaso CR, Pinto AV, et al. Tabebuia avellanedae naphthoquinones: activity against methicillin-resistant staphylococcal strains, cytotoxic activity and in vivo dermal irritability analysis. Ann Clin Microbiol Antimicrob 2006; 5: 5.

9. Blanco E, Bey EA, Dong Y, Weinberg BD, Sutton DM, 
Boothman DA, et al. Beta-lapachone-containing PEG-PLA polymer micelles as novel nanotherapeutics against NQO1overexpressing tumor cells. J Control Release 2007; 122: 365-374.

10. Guiraud P, Steiman R, Campos-Takaki GM, Seigle-Murandi F, Simeon de BM. Comparison of antibacterial and antifungal activities of lapachol and beta-lapachone. Planta Med 1994; 60: 373-374.

11. Cavalcante FA, Silva JLV, Carvalho VMN, Camara CA, Silva TM, Pinto AC, et al. Spasmolytic activity of lapachol and its derivatives, alpha and beta-lapachone, on the guinea-pig ileum involves blockade of voltage-gated calcium channels. Rev Bras Farmacog 2008; 18: 183-189.

12. National Committee for Clinical Laboratory Standards. Reference method for broth dilution antifungal susceptibility testing of yeasts. Approved Standard M27-A3. CLSI. 3rd edn. Villanova: NCCLS; 2002.

13. Capilla J, Maffei CM, Clemons KV, Sobel RA, Stevens DA. Experimental systemic infection with Cryptococcus neoformans var. grubii and Cryptococcus gattii in normal and immunodeficient mice. Med Mycol 2006; 44: 601-610.

14. Santana CF, Lima OG, D'Albuquerque IL, Lacerda AL, Martins DG. Observações sobre as propriedades antitumorais e toxicológicas do extrato do líber e de alguns componentes do cerne do Pau d'arco (Tabebuia avellanedae). Rev Inst
Antib 1968; 8: 89-94.

15. Howland JL. The reversibility of inhibition by 2-heptyl-4-hydroxyquinoline-n-oxide and 2-hydroxy-3(3-methylbutyl)-1,4naphthoquinone of succinate oxidation. Biochim Biophys Acta 1963; 73: 665-667.

16. Schop J. Protective immunity against Cryptococcus neoformans infection. Mcgill J Med 2007; 10: 35-43.

17. Franchimont D, Galon J, Gadina M, Visconti R, Zhou Y, Aringer M, et al. Inhibition of Th1 immune response by glucocorticoids: dexamethasone selectively inhibits IL-12-induced Stat4 phosphorylation in T Iymphocytes. J Immunol 2000; 164: 1768-1774.

18. Moon DO, Choi YH, Kim ND, Park YM, Kim GY. Anti-inflammatory effects of beta-lapachone in lipopolysaccharidestimulated BV2 microglia. Int Immunopharmacol 2007; 7 : 506-514.

19. Hossain MA, Maesaki S, Mitsutake K, Kakeya H, Sasaki E, Tomono K, et al. In-vitro and in-vivo activities of SCH56592 against Cryptococcus neoformans. J Antimicrob Chemother 1999; 44: 827-829.

20. Kakeya H, Miyazaki Y, Senda H, Kobayashi T, Seki M, Izumikawa K, et al. Efficacy of SPK-843, a novel polyene antifungal, in a murine model of systemic cryptococcosis. Antimicrob Agents Chemother 2008; 52: 1871-1872. 